GORAN ZOVAK, Ph.D. ${ }^{1}$

(Corresponding author)

E-mail: goran.zovak@fpz.hr

GORAN KOS, Ph.D. ${ }^{2}$

E-mail: goran.kos@iztzg.hr

BORIS HUZJAN, Ph.D. ${ }^{3}$

E-mail: Boris.Huzjan@hac-onc.hr

${ }^{1}$ University of Zagreb, Faculty of Transport and Traffic

Sciences, Vukelićeva 4, 10000 Zagreb, Croatia

2 Institute for Tourism, Zagreb

Vrhovec 5, 10000 Zagreb, Croatia

3 Croatian Motorways Ltd. - Maintenance and Toll

Collection, Koturaška ulica 43, 10000 Zagreb, Croatia
Traffic on Motorways

Preliminary Communication

Submitted: 22 Feb. 2016

Accepted: 1 Feb. 2017

\title{
THE DRIVER BEHAVIOUR AND IMPACT OF SPEED ON ROAD SAFETY ON THE MOTORWAYS IN CROATIA
}

\begin{abstract}
The paper presents the current research related to the speed of traffic flow on the roads of high serviceability. It analyses the speed of vehicle as one of the main causes of traffic accidents. A flat four-lane motorway section, motorway section in the tunnel and a city bypass section were chosen for this research, and several speed limit scenarios for the vehicles have been applied with the aid of variable signalling. The survey results show that few vehicles respect the speed limits in traffic in the case of a straight section of motorway or city stretch of the motorway which has good geometric elements; however, speed limits are exceptionally well respected in tunnels. Although a large number of drivers do not respect the signs, a certain group of drivers can be influenced by variable signs of limitations, and thus positive changes can be achieved in traffic flow which will result in increasing the traffic safety on the motorways. Thus, increasing the degree of respect for speed limits on the motorways directly affects the increase in the level of traffic safety. It is necessary to influence the group of drivers who do not respect the speed limits with other measures, including repressive ones.
\end{abstract}

\section{KEY WORDS}

motorways; traffic accidents; speed limits; variable message signs;

\section{INTRODUCTION}

For decades, intensive research in the field of road safety has been conducted in the world with the fundamental objective of establishing the mechanisms of occurrence of traffic accidents and the development of new processes, methods and systems for their prevention. Research shows that a significant portion of national wealth is spent on dealing with the consequences of road accidents. The analysis of the current situation shows the fact that the costs of traffic accidents can be from 2 to 4 and more percent of GDP for countries within the European Union [2]. According to the World Health Organization, the expense of one fatality in a car accident is estimated at one million euro [1]. Road traffic safety represents complex relationships between humans, roads, vehicles and various incident factors. By acting on each individual factor, the road safety can be improved and the number of traffic accidents reduced. The road safety policy of the European Union aims to raise the level of road safety and provide a secure and easy mobility of citizens across Europe. The top countries in terms of prevention of casualties on the roads are Sweden, England, the Netherlands and Denmark, while Croatia, Poland, Lithuania, Latvia and Romania are at the bottom. In the Republic of Croatia, in the last ten years (from 2005 to 2014), 4,955 persons were killed in traffic and 36 thousand were seriously injured [4]. In 26 percent of accidents the victims were people, that is, an average of 23 thousand people lost their lives in traffic in a year. Out of these 79.5 percent suffered from minor injuries. Eighteen percent of the people suffered from serious injuries and 2.5 percent of people lost their lives in a year, which means an average of 582 persons per year. According to the lowest estimates of experts in security and economic analysts, Croatia has a direct loss of at least 2 to 4 percent of GDP due to traffic accidents, while indirect losses are multiple [3]. One of the main causes of traffic accidents is unadjusted speed of vehicles. It was speeding that led to the highest number of fatalities. This paper focuses on research related to the speed of vehicles on the roads with high levels of service and drivers speed compliance in various real and simulated conditions with ITS technology (Variable Message Signs). The research presented in this paper was carried out in the framework of the 
Scientific Research Project of the $7^{\text {th }}$ Framework Programme of the European Commission "Intelligent Cooperative Sensing for Improved Traffic Efficiency" 2012-2013, EC-FP7-317671, in which activities are carried out related to the improvement of the system of variable speed limit (Variable Speed Limit Control - VSL Control). The research was done on the motorways in the Republic of Croatia by video-counters, and recording covered more than 300,000 vehicles.

\section{LITERATURE REVIEW}

The research of vehicle speed, its impact on safety in traffic flows, and its limits started to be conducted with the advent of modern vehicles. After the first study of the characteristics of traffic flow in 1964 the Solomon's paper described relations between the speed of vehicles and the risk of occurrence of traffic accidents [5]. This relationship is a U-shaped function, where the risk of the event of an accident is the lowest around the average speed of about $105 \mathrm{~km} / \mathrm{h}$, and the highest in the outermost limits of the minimum and maximum speeds of traffic flows (25 and $135 \mathrm{~km} / \mathrm{h}$ ). In their paper, Garber and Gadiraju (1988) were first to describe the changes in the traffic flow speed (speed variance) and their impact on the event of traffic accidents [6]. Farmer et al. (1996) conducted a survey on changes in speed limits and deaths of passengers in motor vehicles [7]. The change of speed of the traffic flow was also studied through the scientific research project the seventh frame programme from the EU commission "Intelligent Cooperative Sensing for Improved Traffic Efficiency” 2012 - 2013, EC-FP7-317671 Variable Speed Limit Control - VSL Control [8]. The latest studies of traffic flow and the influence of changes in speed in the traffic flow to traffic safety are found in the paper by Heydecker and Addison (2011), in which the relationship between speed and density was developed to analyze traffic flow within the variable speed and the relationship between speed and density of the traffic accidents [9]. Thomas et al. (2012) made an advanced speed-volume model for heterogeneous traffic flow on six-lane motorways [10]. The use of GPS systems for the analysis of free-flow traffic and monitoring of the speed of vehicles was described by Bekhor et al. (2013) [11]. The speed was considered as the leading cause of traffic accidents, as a result of which a model was developed to control the speed on the national level. The paper by Jalooli et al. (2014) researched the variable speed limits (VSL - variable speed limits) with respect to the type and size of vehicles for given traffic and weather conditions on the roads [12]. Yang-Won (2014) made The Activation Plan of Variable Speed Control of Considering Urban Freeway (In Busan Metropolitan City) [13]. Moon and Ko (2014) in their paper "Vehicle Speed Measurement using SAD
Algorithm" proposed a mechanism by which traffic flow and speed of vehicles on the motorways can be measured by using video cameras to detect traffic [14]. Mehar et al. (2014) conducted a research of capacity of four-lane motorway for mixed traffic conditions by VISSIM simulation tool, to check, according to real measuring, the applicability of simulation [15]. The prediction of flow, density and the speed of traffic flow have wide application in many areas, using neural networks, developed by Park et al (2014) in the paper "Intelligent Trip Modelling for the Prediction of an Origin-Destination Travelling Speed Profile" [16]. The paper by Hooper et al. (2014) determined the relationship between traffic flow and precipitation based on research done on the motorways in England [17]. Wang et al. (2014) examined the effect of asphalt surfacing roughness (abrasion) on the speed of free flow [18], while Theofilatos (2014) gave an overview of the effects of traffic and climate characteristics on the road safety [19]. The phenomenon of occurrence of bottlenecks on the motorways and blocking traffic was considered in the work of Mendes et al. (2014) and Chen et al. (2015) [20, 21]. Recent works (2015) based on the research of movement of vehicles on the motorways were made by Grumert [22], Seo [23], Chang [24], Montella [25], Jamshidnejad [26], and the paper in which basic parameters of traffic flow in cities are explored (Horvat et al., 2015.) [27].

\section{ROAD TRAFFIC SAFETY IN THE REPUBLIC OF CROATIA AND ON THE RIJEKA- ZAGREB MOTORWAY}

According to the Bulletin data on the road safety 2014 [4], in the period 1965 to 2014 , there were 47,514 people who lost their lives on the Croatian roads. When comparing the period from 2005 to 2014 about 470 thousand traffic accidents happened on the Croatian roads. In these accidents 201,000 people were injured, 4,955 people lost their lives, 36 thousand people were severely injured and 160 thousand people were slightly injured [4].

The annual number of fatalities in traffic in the Republic of Croatia 25 years ago (1980) amounted to about 1,600 but today the number has decreased over five times and amounts to 309 fatalities each year. In addition to improving the quality of roads which resulted in the reduction of the number of accidents and their consequences, significant advances have been made through the development of safer vehicles, their maintenance and control, through the education of all traffic participants and other factors. What has remained unchanged over the years is the fact that excessive speed is the main cause of traffic accidents.

Forty percent of accidents on the Rijeka - Zagreb motorway occurred because of the speed that was 
not adjusted to driving conditions on the road, 14 percent of accidents due to keeping inadequate distance, 13 percent due to failure to comply with the benefits of passage, 5 percent due to improper merging, 5 percent due to improper turn, while the rest (23 percent) belongs to other causes [4].

Figure 1 shows the ratio of the number of accidents and the speed limit at the moment of the accident. It can be concluded from the data that the majority of accidents (51 percent) occurred in the conditions when there were no additional speed limits on the motorway, or at normal speed limit of $130 \mathrm{~km} / \mathrm{h}$. If permanent speed limits $-130 \mathrm{~km} / \mathrm{h}$ on the lowland section, $110 \mathrm{~km} / \mathrm{h}$ on the hill section and $100 \mathrm{~km} / \mathrm{h}$ in tunnels are singled out in a special group, and the temporary speed restrictions set by a system of variable speed limits in a special group, the results shown in Figure 1 are obtained.

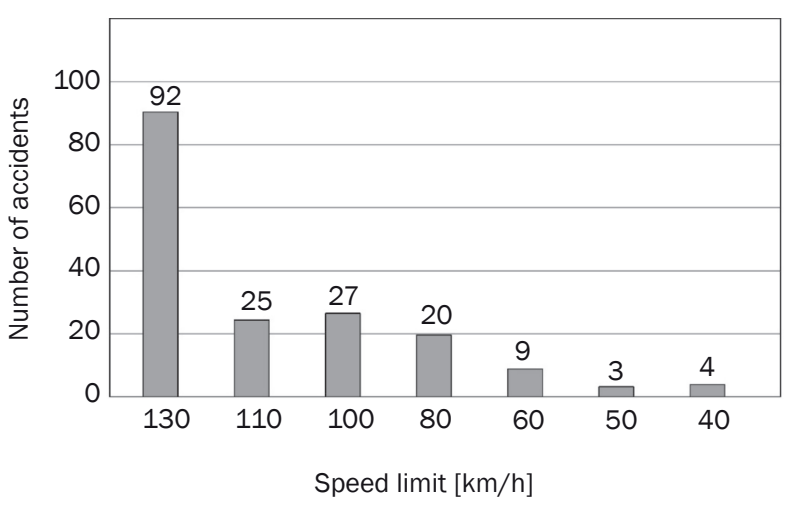

Figure 1 - The number of accidents by speed limit

Also, the analysis concludes that the majority of accidents (almost 70 percent) were created in the conditions in which there were no temporary speed restrictions set by the system of variable speed and that a very small number of accidents occurred in the conditions in which temporary speed restriction was active. The fact that a part of accidents decreased with the lower temporary speed restriction is also significant. The conducted analysis of the existing statistical data indicates that the largest number of accidents occurs on standard motorway sections under normal weather conditions and that the cause of these accidents is unadjusted speed or insufficient distance between the vehicles.

\section{METHODOLOGY OF RESEARCH}

\subsection{Method of research}

For the purpose of this work a field research was made to determine the extent to which the drivers on the motorways in Croatia respect the speed limit signs. The research was done on the motorway sections between Zagreb and Rijeka and Rijeka Bypass in the Republic of Croatia. During the research, made in 2013 through 2015, traffic flow on the motorway with all the parameters of a total duration of ten days was recorded by video-counters, and the recording covered more than 300,000 vehicles.

\subsection{Measurement locations}

As a typical cross section for measurement, three locations were selected on the A1 motorway Zagreb-Bosiljevo, and A7 Rijeka Bypass. The selected locations are situated in the direction of travel, behind the portal with variable message signs for speed limit. The distance of measurement position (position meter) from the portal with variable message signs for speed limit is determined in such a manner that sufficient distance for the vehicle to pass with free deceleration (without braking) is calculated from the maximum allowed speed, slowing down to the speed limited by the variable message sign. The locations were also selected so that the selected motorway sections represent different driving conditions with different allowed speeds in normal conditions of traffic flow and normal weather conditions. The selected locations were:

Location 1: A1 motorway, Jastrebarsko - Donja Zdenčina section, after interchange Zdenčina to Karlovac normal cross-section of the motorway - the limit is 130 $\mathrm{km} / \mathrm{h}$,

Location 2: A1 motorway, Novigrad - Karlovac section, after tunnel Sveti Marko to Novigrad - driving in tunnel - limit $100 \mathrm{~km} / \mathrm{h}$, and

Location 3: A7 motorway, Rijeka Bypass, after tunnel Katarina in the direction of Zagreb - complex motorway alignment - Rijeka Bypass - limit $60 \mathrm{~km} / \mathrm{h}$.

On Location 1, speed measuring was conducted to determine how much the drivers respect the speed limits on the variable message signs on the flat section of the motorway, on flat terrain without any external influence that might cause the driver to reflexively/ spontaneously reduce speed (rain, fog, works, etc.). On Location 2, speed measuring was conducted to determine how much the drivers respect the speed limits on the variable message signs on the motorway section on a hill terrain in a tunnel without any external influence that might cause the driver to reflexively/ spontaneously reduce speed (rain, fog, works, etc.). On Location 3, speed measuring was conducted to determine how much the drivers respect the speed limits on the variable message signs on the motorway section which is at the same time a city bypass. The distances from the portal to the location of measurement are determined based on the difference in speed reduction for each survey and they are 200 to $400 \mathrm{~m}$ except in tunnels, where the distance was $180 \mathrm{~m}$. 


\subsection{Measuring scenarios}

On Location 1 (A1 motorway, Jastrebarsko - Donja Zdenčina section), the measurement was conducted in three scenarios while at other locations the measurements were carried out in one scenario. Different scenarios on Location 1 were achieved by changing the value of the speed limit on the variable message sign. In this way, the following scenarios were planned on Location 1:

Scenario 1 - variable speed limit sign was turned off; it is examined how much the drivers respect a static sign of speed restriction $(130 \mathrm{~km} / \mathrm{h})$.

Scenario 2 - on variable message sign for speed restriction $100 \mathrm{~km} / \mathrm{h}$ speed limit is active; it is examined how much the drivers respect lower speed reduction of the maximum allowed speed, shown on the dynamic sign, without the surrounding factors that would influence reflexive (spontaneous) speed reduction.

Scenario 3 - on variable message sign for speed restriction $80 \mathrm{~km} / \mathrm{h}$ speed limit is active; it is examined how much the drivers respect lower speed reduction of the maximum allowed speed, shown on the dynamic sign, without the surrounding factors that would influence reflexive (spontaneous) speed reduction.

On other locations the parameters of traffic flow with static speed limit $(100 \mathrm{~km} / \mathrm{h}$ on Location 2 and $60 \mathrm{~km} / \mathrm{h}$ on Location 3) were measured.

\section{MEASUREMENT RESULTS}

\subsection{Location 1: A1 motorway, Jastrebarsko - Donja Zdenčina section}

On this location the traffic was recorded during the tourist season. A sample of 57,000 vehicles was covered by this measurement. On the same section, but on the location one kilometre further from the first one, additional recording of traffic flow was carried out for the analysis of difference of traffic flow characteristics on two slightly remote locations. Additional recording of traffic flows was performed a week after the primary measurement. The speed limit on the observed section is $130 \mathrm{~km} / \mathrm{h}$. It is possible to change the speed limit on the section by activating the variable speed limit sign. The first part of the analysis includes an analysis of average speed of all vehicles during the total period of recording the flows. The ratio of the speed limit and the average speed of vehicles in hourly measurement intervals is shown in Figure 2. Figure 2 shows that the average speed of vehicles is $120-140 \mathrm{~km} / \mathrm{h}$, and that it depends on the time of day, or that the speed is higher during day than at night. The reasons of this relationship are different (visibility, traffic flow structure, etc.). During the day, in normal weather conditions (no rain, fog, etc.) and in normal conditions of traffic flow (levels of traffic services are greater than $\mathrm{D}$ ) the average speed of vehicles is about $140 \mathrm{~km} / \mathrm{h}$ which is $10 \mathrm{~km} / \mathrm{h}$ more than the limit. The picture shows the dependence of the average speed of vehicles and the value of the speed limits on the variable message sign, which is proof that drivers perceive and give particular importance to warnings on variable message signs and react by reducing speed. The reduction of the average speed of all vehicles when the speed is limited by variable message sign from $130 \mathrm{~km} / \mathrm{h}$ to $100 \mathrm{~km} / \mathrm{h}$ is $6 \mathrm{~km} / \mathrm{h}$, while reduction in the average speed when the speed is limited by variable message sign from $130 \mathrm{~km} / \mathrm{h}$ to $80 \mathrm{~km} / \mathrm{h}$ is $9 \mathrm{~km} / \mathrm{h}$. Reduction in average speed compared to the speed limited by traffic signs is small and the average speed of all vehicles is high above the limit, but the existence of dependence is visible.

After determining that drivers perceive the limitations of variable traffic signs it is necessary to determine the distribution at which vehicles are distributed depending on the limitations of variable traffic signs and also depending on the conditions of traffic flow and weather conditions. In order to determine this, the histogram of the driving speed during each observed time interval has been made. Therefore, the speed is divided into intervals of $5 \mathrm{~km} / \mathrm{h}$ starting from the speed of $60 \mathrm{~km} / \mathrm{h}$ as shown in Figure 3-A, which represents the recording time interval from 13:00-14:00 on $20^{\text {th }}$ June 2013 , when the speed was not limited by variable signs, that is, when the speed was limited to $130 \mathrm{~km} / \mathrm{h}$.

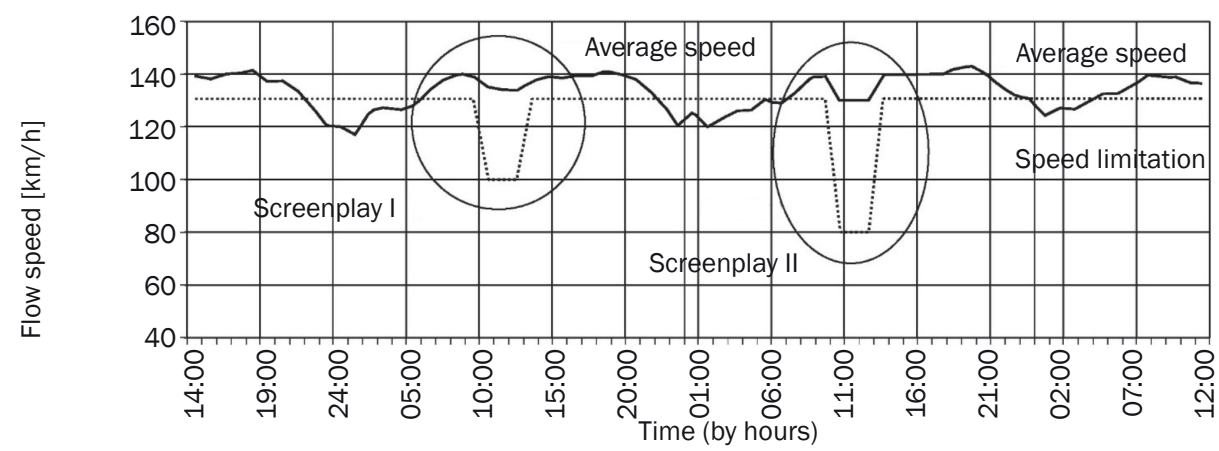

Figure 2 - The traffic flow speed by time (each hour) 
A Histogram: 20.6.2013. 13-14h, speed $v=130 \mathrm{~km} / \mathrm{h}$, vehicles $<6 \mathrm{~m}$

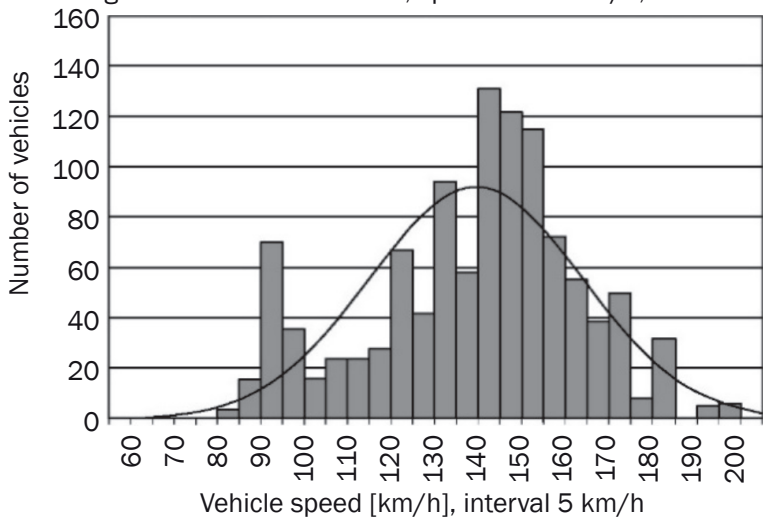

C Histogram: 19.6.2013. 11-12h, speed v=100km/h, vehicles $<6 \mathrm{~m}$

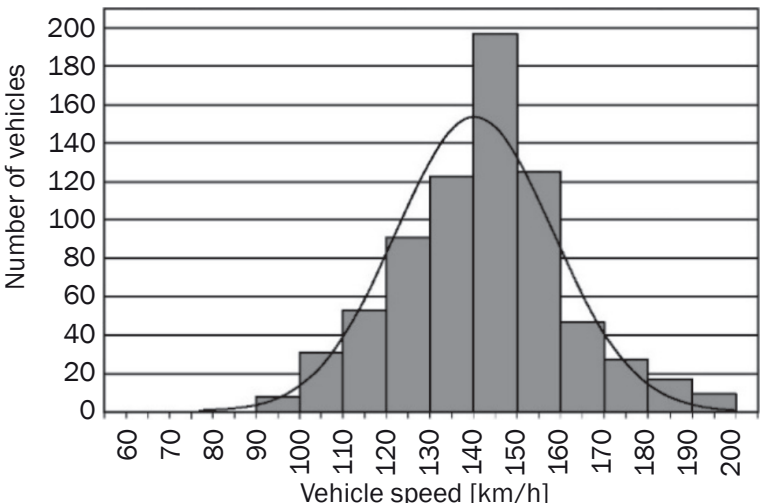

B Histogram: 20.6.2013. 13-14h, speed v $=130 \mathrm{~km} / \mathrm{h}$, vehicles $<6 \mathrm{~m}$

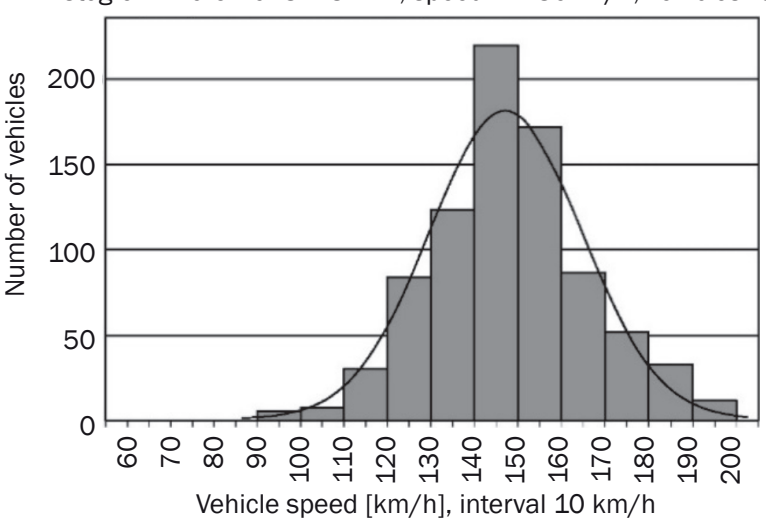

D Histogram: 20.6.2013. 12-13h, speed $v=80 \mathrm{~km} / \mathrm{h}$, vehicles $<6 \mathrm{~m}$

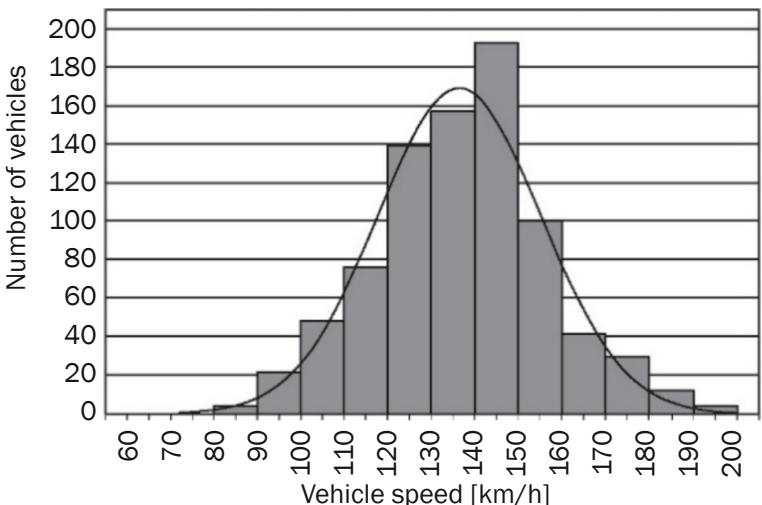

Figure 3 - Histogram of speed interval on Location 1

Looking at the results of Figure 3-A a lot of non-compliance with speed limited by fixed traffic signs can be seen, which in this case is limited to $130 \mathrm{~km} / \mathrm{h}$. The analysis of Figure 3 also found the existence of a much larger share of speed than expected in the range between 80 and $100 \mathrm{~km} / \mathrm{h}$ as well as in the interval between 140 and $160 \mathrm{~km} / \mathrm{h}$. The analysis of the recorded results also showed the existence of vehicles longer than 6 meters (freight vehicles) in the amount of 26.92 percent. Specifically, those are vehicles with a legal ban on the driving speed higher than 80,90 or $100 \mathrm{~km} / \mathrm{h}$ (depending on vehicle type) on the motorways. Since such vehicles are operated by professional drivers who generally respect the speed limits, the specified group of vehicles is excluded from the sample.

Based on the results shown in Figure 3 it can be seen that the distribution goes at normal distribution. It has been determined by statistical calculation that the amount of standard deviation $(\sigma)$ is 24.47 , while the mean is (MEAN) 139.01, mode is 157.71 and median 144.61. This is another confirmation that this is a normal distribution since the arithmetic mean, mode and median have approximately the same values. IIlogical dispersion of results with other values of speed has also been established so the distribution with double the interval or interval of $10 \mathrm{~km} / \mathrm{h}$ has been tested and a significantly better result was obtained.
The histogram with an interval of $10 \mathrm{~km} / \mathrm{h}$ is shown in Figure 3-B. Based on the distribution shown in Figure 3 the values of standard deviation were obtained $(\sigma)$ 16.76, the arithmetic mean (MEAN) is 142.87, mode is 146.44 and median is 143.23 . Looking at the resulting parameters of the normal distribution it can be seen that by excluding freight vehicles the average speed has increased from 139.01 to $142.87 \mathrm{~km} / \mathrm{h}$ and the dispersion of speed $(\sigma)$ has decreased from 21.41 to 16.76. Analysing the results in Table 1 and comparing them with the restrictions, it was noted that in the course of speed restriction by variable message sign a reduction in the average speed occurs, but it also leads to an increase in the standard deviation, that is, the dispersion of speed increases while increasing the speed limit.

Table 1 - Statistical result of graphs in Figure 3

\begin{tabular}{||c|c|c|c||}
\hline & $\begin{array}{c}\text { No speed } \\
\text { limit }\end{array}$ & $\begin{array}{c}\text { Limit at } \\
100 \mathrm{~km} / \mathrm{h}\end{array}$ & $\begin{array}{c}\text { Limit at } \\
80 \mathrm{~km} / \mathrm{h}\end{array}$ \\
\hline \hline $\begin{array}{c}\text { Arithmetic } \\
\text { mean }\end{array}$ & 147.299 & 141.867 & 136.586 \\
\hline Median & 148.056 & 141.618 & 136.791 \\
\hline Mode & 152.884 & 146.446 & 140.009 \\
\hline $\begin{array}{c}\text { Standard } \\
\text { deviation }\end{array}$ & 18.609 & 18.991 & 20.032 \\
\hline
\end{tabular}




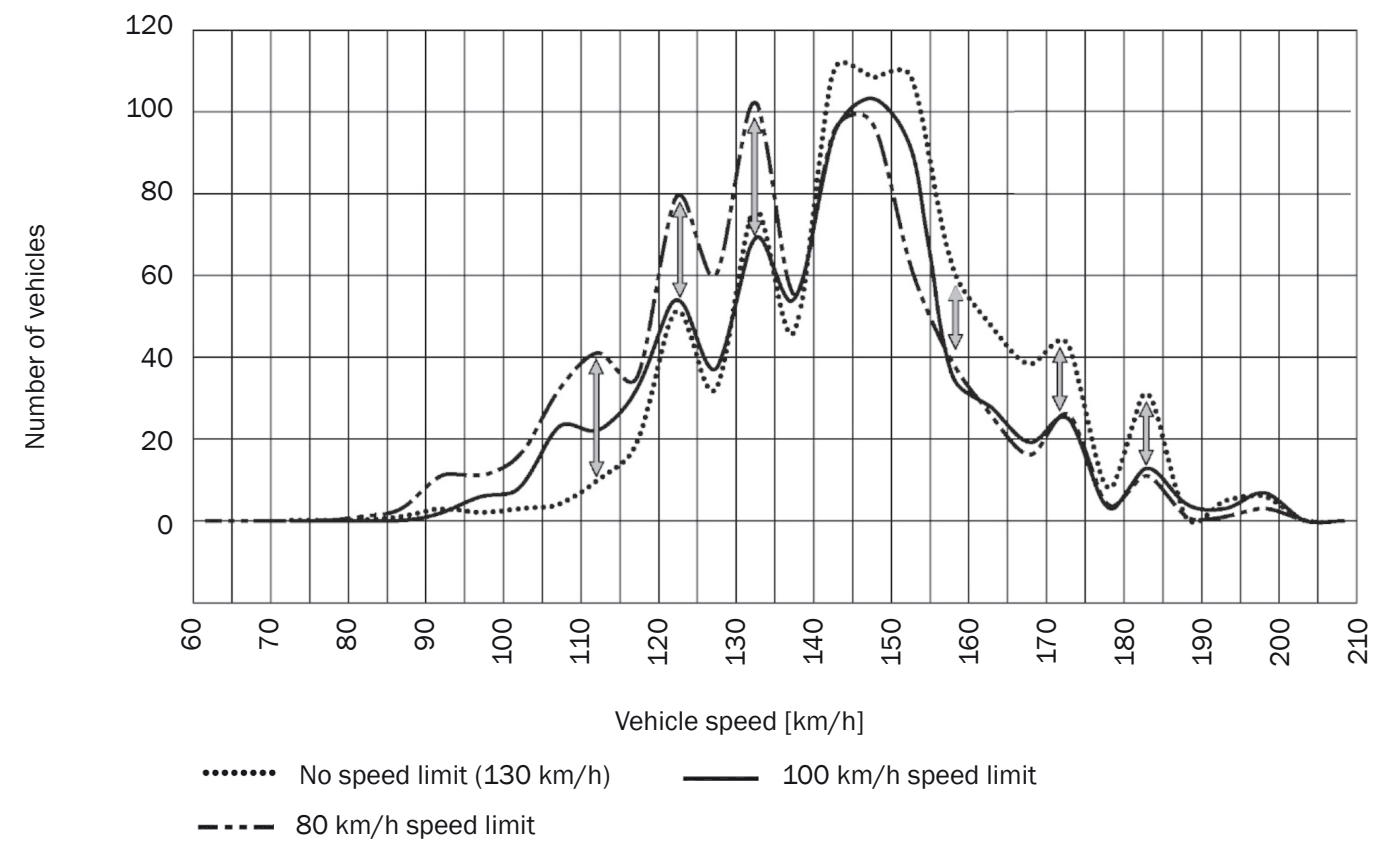

Figure 4 - Overview of the number of vehicles driving at a certain speed depending on the speed limit

Based on the research, it can be concluded that when the restriction on the variable message sign on the motorway is switched on, two categories of drivers occur: those who respect the limit and those who do not. These two categories are more clearly seen in Figure 4 which shows the number of vehicles driving at a certain speed depending on the speed limit. Looking at Figure 4 it can be seen that before and after the interval the speed is $135-140 \mathrm{~km} / \mathrm{h}$, depending on the restriction, there are big differences in reduction or increase of certain speed intervals which leads to the conclusion about the behaviour of two different groups of drivers. A group of drivers that is significantly affected by the change of speed limit occurs and a second group of drivers that does not show too much influence of restriction on the reduction of their driving speed causing an increase in the standard deviation, that is, dispersion of speed. Figure 4 clearly shows that the increase in the number of speed reduction cases for speeds which are higher than the interval $135-140 \mathrm{~km} / \mathrm{h}$, is significantly lower than the increase in the number of speed increase cases that are less than the interval $135-140 \mathrm{~km} / \mathrm{h}$, which leads to the conclusion that drivers who drive significantly above the limit ( $140 \mathrm{~km} / \mathrm{h}$ or more) acknowledge less the warning of speed limited by variable message sign in relation to the drivers who drive within the speed limit (interval from 130 to $135 \mathrm{~km} / \mathrm{h}$ ).

As further step in the analysis of compliance with the speed limits, an analysis of vehicle speed by percentiles has been made. In the scenario in which there was no speed limit, $85^{\text {th }}$ percentile speed amounted to $165.8 \mathrm{~km} / \mathrm{h}$. In a scenario in which the speed limit was $100 \mathrm{~km} / \mathrm{h}, 85^{\text {th }}$ percentile speed was $157.7 \mathrm{~km} / \mathrm{h}$.
Detailed speed analysis by percentiles shows the results in Table 2.

Table 2 - Overview of speed by percentiles

\begin{tabular}{||c|c|c|c||}
\hline \hline Percentile & No limit & $\begin{array}{c}\text { Limit at } \\
100 \mathrm{~km} / \mathrm{h}\end{array}$ & $\begin{array}{c}\text { Limit at } \\
80 \mathrm{~km} / \mathrm{h}\end{array}$ \\
\hline \hline 90 & 170.6 & 165.6 & 160.9 \\
\hline 80 & 160.9 & 154.5 & 152.9 \\
\hline 70 & 154.5 & 152.9 & 146.4 \\
\hline 60 & 152.9 & 146.4 & 140.0 \\
\hline 50 & 148.1 & 141.6 & 136.8 \\
\hline 40 & 141.6 & 138.4 & 132.0 \\
\hline 30 & 138.4 & 132.0 & 127.1 \\
\hline 20 & 132.0 & 124.2 & 120.7 \\
\hline 10 & 123.9 & 115.9 & 111.0 \\
\hline
\end{tabular}

From the shown results it is clear that the speed changes, that is, it is reduced by individual percentiles depending on the speed limited by variable message signs from which it can be concluded that the drivers perceive the speed limit through variable traffic signs in the conditions of normal traffic flow as well as in normal weather conditions. When observing the speed limit on the motorway in normal driving conditions which is $130 \mathrm{~km} / \mathrm{h}$ it can be seen that it appears around $20^{\text {th }}$ percentile, or $30^{\text {th }}$ and $40^{\text {th }}$ percentile in case when it comes to reducing speed by variable message signalling to $100 \mathrm{~km} / \mathrm{h}$ or $80 \mathrm{~km} / \mathrm{h}$, which speaks additionally of a large amount of vehicles which do not respect the speed limit on the motorways of the Republic of Croatia. 


\subsection{Location 2: A1 motorway, Novigrad - Karlovac section}

The aim of recording the traffic on Location 2 was to analyse the respecting of the speed limits through variable message signs on the motorway section which is located in the tunnel where the normal driving speed is limited to $100 \mathrm{~km} / \mathrm{h}$. An overview of the dependency of the average driving speed of a certain hour, depending on the speed limit is given in Figure 5. The results of recording traffic show that there are very few hours (only 5 out of 127 hours which is from 14:00 to 19:00) during the recorded period when the average driving speed per hour is higher than the speed limit.

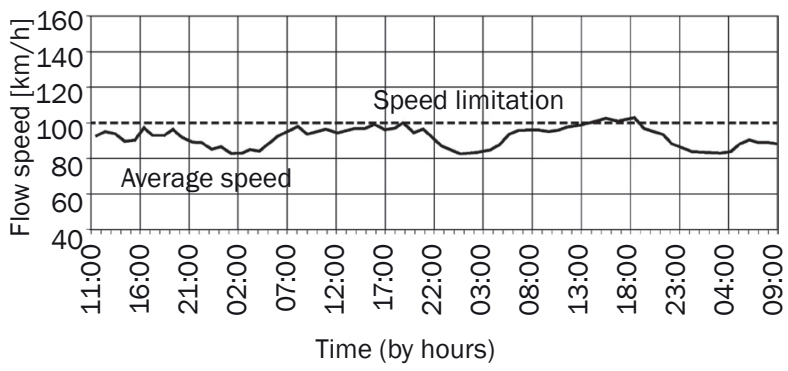

Figure 5 - Ratio of average driving speed of each hour and speed limit in the tunnel

\subsection{Location 3: A7 motorway, Rijeka Bypass}

The aim of recording the traffic on Location 3 was to analyse the respecting of the speed limits through variable message signs on a complex motorway section which is also a bypass and the usual driving speed is limited to $60 \mathrm{~km} / \mathrm{h}$. An overview of dependence of the average driving speed of each hour depending on the speed limit is given in Figure 6. The results of recording traffic show that there are very few hours (only 1 out of 143 hours) during the recorded period when the average speed in an hour was within the speed limit, or 99 percent of the hours have a higher average speed than allowed, while 93 percent of hours have speed over $100 \mathrm{~km} / \mathrm{h}$.

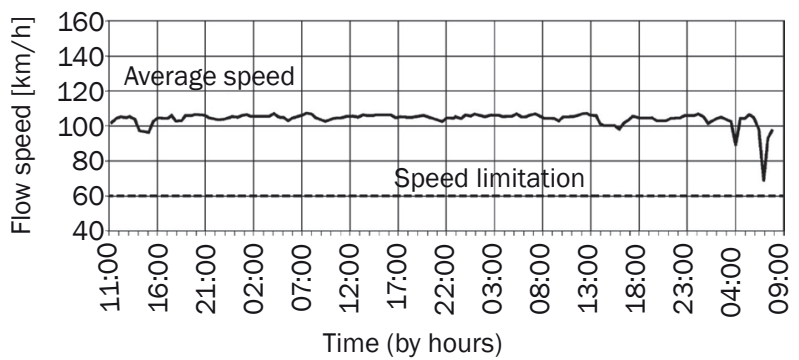

Figure 6 - Ratio of average driving speed of each hour and speed limit on the city bypass

\subsection{Recommendations for the implementation of the traffic control system}

Final results of measurements according to various scenarios are shown in Figure 7. According to different speed limits, due to weather conditions, different results of average traffic were obtained. On the flat section of the motorway the average speed of traffic flow was measured during the day and with all types of restrictions, as well as the city bypasses. Exceeding of the speed limit makes a group of drivers who drive significantly faster than the limits and respect less the speed limits in relation to drivers who drive below the

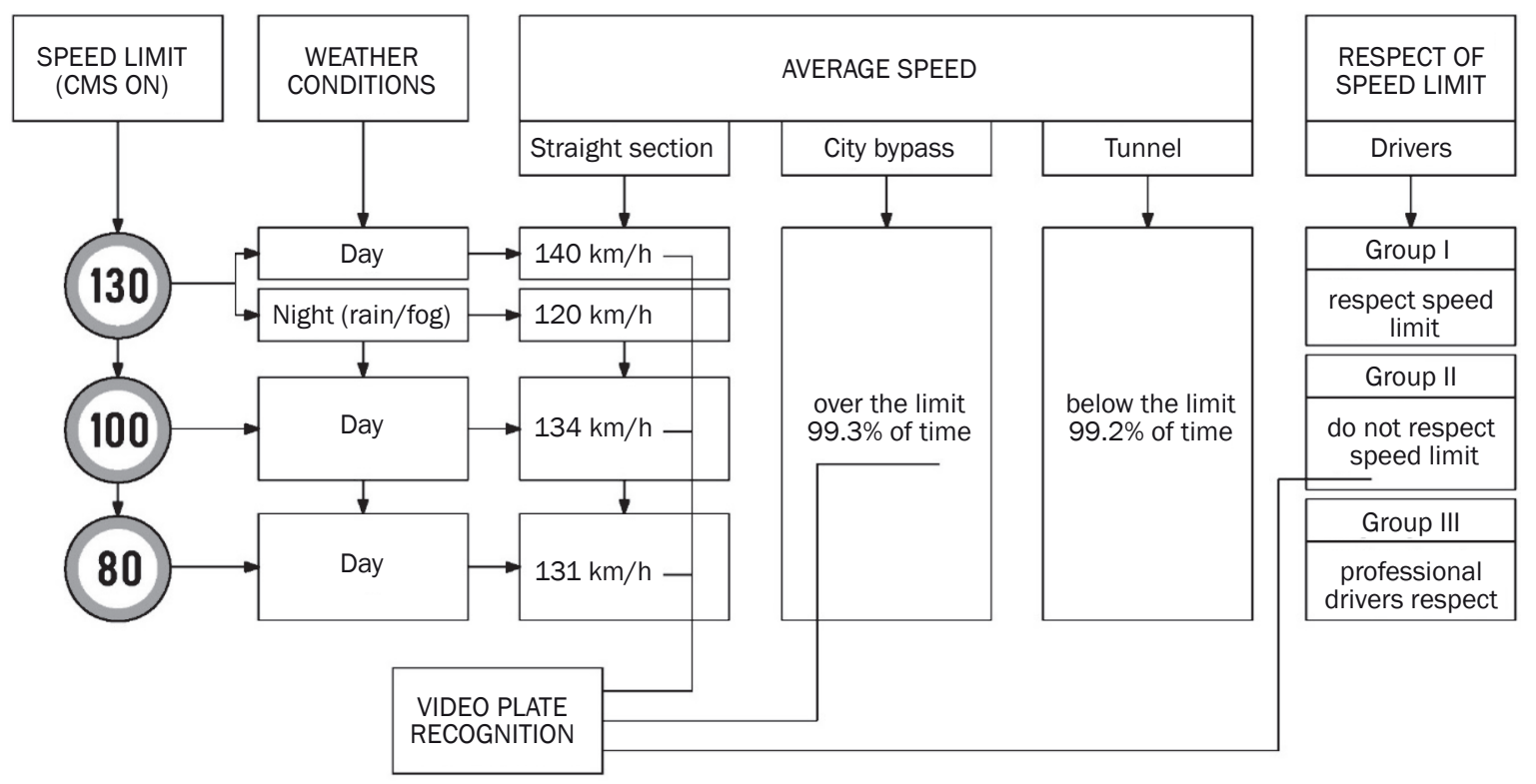

Figure 7 - Graphical representation of speed measurement on highways for setting up systems for traffic speed monitoring 
speed limits. Figure 7 shows suitable places for setting up systems for traffic speed monitoring and the group of drivers that should be affected.

According to the algorithm in Figure 7, in the first step, it is necessary to measure the average speed of vehicles in different segments of transport infrastructure. One can choose a flat section, city bypass, tunnel, viaduct, bridge, underpass, overpass, etc. In these places a system of recognition of license plates can be installed and the driver of such a vehicle can be automatically sanctioned. According to the algorithm, it is obvious that the system for recognition of license plates of cars should not be placed in the tunnels. The tunnel average speeds are almost always under constraints. However, the system should be placed on the city ring road and the flat parts of the highway since the speed limits there are almost never respected.

\section{DISCUSSION}

The first research of traffic flow speed on the motorways with three scenarios was conducted on the A1 motorway on the Jastrebarsko - Donja Zdenčina section. From the analysis of the average speed of all vehicles during the entire measuring period the following can be concluded:

- speed limit of $130 \mathrm{~km} / \mathrm{h}$; average speed of all vehicles on the flat sections is from 120 to $140 \mathrm{~km} / \mathrm{h}$ and it depends on the time of day, that is, the speed is higher during the day than during the night. The reasons of this relationship are various (visibility, structure of traffic flow, etc.). During the day, in normal weather conditions (no precipitation, fog, etc.) and in normal traffic flow conditions (level of traffic service is greater than D) the average speed of all vehicles is approximately $140 \mathrm{~km} / \mathrm{h}$ which is by 10 $\mathrm{km} / \mathrm{h}$ higher than the speed limit,

- speed limit of $100 \mathrm{~km} / \mathrm{h}$; reducing the average speed of all vehicles when speed is limited by variable message sign from $130 \mathrm{~km} / \mathrm{h}$ to 100 $\mathrm{km} / \mathrm{h}$ is $6 \mathrm{~km} / \mathrm{h}$,

- reduction in average speed when speed is limited by variable message sign from $130 \mathrm{~km} / \mathrm{h}$ to 80 $\mathrm{km} / \mathrm{h}$ is $9 \mathrm{~km} / \mathrm{h}$,

- when limiting the speed by variable message sign, a decrease of average speed occurs, but it also leads to increasing standard deviation, that is, speed dispersion is increased when speed limit is increased,

- analysis of fast freight vehicles shows that they respect the speed limit since it refers to vehicles with a legal ban on the speed of 80,90 or $100 \mathrm{~km} / \mathrm{h}$ (depending on the type of vehicle) on the motorways and such vehicles are operated by professional drivers who, generally, always respect the speed limit,
- therefore, drivers perceive the speed limits that are displayed on variable message signs and give certain importance to the warnings and react by reducing the speed, but the reduction in average speed compared to the speed limited by the traffic signs is small. The average speed of all vehicles is high above the limit, so it is possible to conclude that a part of the drivers respect the limits displayed on a traffic sign.

The second research carried out on the motorway section which is located in the tunnel with a speed limit of $100 \mathrm{~km} / \mathrm{h}$, and the obtained results of the analysis show that:

- there is a very small number of hours ( 0.8 percent) during the recorded period when the average speed of driving in the hour is higher than the speed limit, - that is, from the above mentioned it can be concluded that drivers adjust their speed of driving to external factors, in this case the influence of lateral interference (tunnel walls, illumination, etc.).

The third research analysed the respecting of the speed of driving limited by variable message signs on a complex motorway section which is at the same time a bypass, and usual driving speed is limited to 60 $\mathrm{km} / \mathrm{h}$. The analysis of the results of traffic recording shows that:

- there is a very small number of hours ( 0.7 percent) during the recorded period when the average driving speed in an hour was within the speed limit,

- that is, from the above it can be concluded that the drivers on the motorway section which features construction and geometric elements for higher speeds than the signs permit, generally do not respect the speed limit, but drive at speeds that are closer to the computational elements of the road (in this case the computational speed of the road is $90 \mathrm{~km} / \mathrm{h}$ ).

\section{CONCLUSION}

Drivers insufficiently respect speed limits on motorways, but there is a strong dependence of the average speed of traffic flow and speed limit which indicates that a certain part of drivers still respect the speed limits so when activating the restriction on the variable message sign on the motorway, two categories of drivers occur, one that respects the limit and the other one that does not (61.5 percent).

Before and after the speed interval of 135-140 $\mathrm{km} / \mathrm{h}$, depending on the restriction, there are big differences in the reduction or increase in the number of vehicles in certain speed intervals, which leads to the conclusion about the behaviour of two different groups of drivers. One group of drivers is significantly affected by the change of speed limit and the second group of drivers does not show too much influence of 
restriction on the reduction of their driving speed causing an increase in the standard deviation, that is, dispersion of speed. This leads to the conclusion that drivers who drive significantly above the limit $(140 \mathrm{~km} / \mathrm{h}$ or more) acknowledge less the warning of speed limited by variable message sign in relation to the drivers who drive within the speed limit (interval from 130 to 135 $\mathrm{km} / \mathrm{h})$.

The research results of respecting the speed limit on the motorway section through the tunnel show significantly better compliance with speed limits. The results show that drivers almost fully respect the speed limit in a tunnel.

From the conducted research of respecting the speed limited by variable message signs it can be concluded that, although a large number of drivers does not respect such signs, there is a certain group of drivers who can be influenced by variable speed limit message signs and that this can achieve positive changes in traffic flow which will result in increased security of the traffic flow on the motorway. Thus, increasing the degree of respecting the speed limits on the motorways directly affects the increase in the level of traffic safety. On the other hand, it is necessary to detect a group of drivers that does not respect the speed limit by using video surveillance and act on these drivers by implementing the penal system.

\section{Prof. dr. Sc. GORAN ZOVAK ${ }^{1}$}

E-mail: goran.zovak@fpz.hr

Prof. dr. sc. GORAN KOS ${ }^{2}$

E-mail: goran.kos@iztzg.hr

Dr. sc. BORIS HUZJAN ${ }^{3}$

E-mail: Boris.Huzjan@hac-onc.hr

${ }^{1}$ Sveučilište u Zagrebu, Fakultet prometnih znanosti

Vukelićeva 4, 10000 Zagreb, Hrvatska

2 Institut za turizam, Vrhovec 5, 10000 Zagreb, Hrvatska

${ }^{3}$ Hrvatske autoceste održavanje i naplata cestarine d.o.o. Koturaška ulica 43, 10000 Zagreb, Hrvatska

\section{UTJECAJ PONAŠANJA VOZAČA I BRZINE VOZILA NA SIGURNOST PROMETA NA AUTOCESTAMA U REPUBLICI HRVATSKOJ}

\section{SAŽETAK}

U ovom radu prikazana su trenutna istraživanja vezana uz brzinu protoka prometa na cestama visoke upotrebljivosti. Također, analizirana je brzina vozila kao jedan od glavnih uzroka prometnih nesreća. Za istraživanje je odabrana dionica autoceste s četiri traka, dio autoceste s tunelom, dio gradske obilaznice, te nekoliko dionica gdje se primjenjivalo ograničenje brzine uz pomoć promjenjive signalizacije. RezuItati ankete pokazuju da pojedini vozači poštuju ograničenja brzine na cesti u slučaju ravnog dijela autoceste ili grada te $u$ dijelu autoceste koja ima dobre geometrijske elemente. Međutim, najveće zabilježeno poštivanje ograničenja brzine je u tunelima. lako je veliki broj vozača koji ne poštuju prometne znakove, uvijek postoji određena skupina vozača koja će poštivati promjenjive znakove ograničenja, a samim time mogu se postići i pozitivne promjene $u$ brzini prometnog toka koje će rezultirati povećanjem sigurnosti prometa na autocestama. Dakle, povećavajući stupanj poštivanja ograničenja brzine na autocestama, izravno se utječe na povećanje razine sigurnosti u prometu. Zato je potrebno utjecati na skupinu vozača koji ne poštuju ograničenje brzine uz pomoć drugih mjera, uključujući i represivne mjere.

\section{KLUUČNE RIJEČI}

autoceste; prometne nesreće; ograničenja brzine; promjenjivi prometni znakovi;

\section{REFERENCES}

[1] Global Health Observatory on Health Research and Development. World Health Organisation; 2013.

[2] External Costs of Transport in Europe. CE Delft, Infras, Fraunhofer ISI; 2008.

[3] Massnahmen gegen Unfallhaufungen Auswertung von Strassenverkehrs-unfallen, Teil 1. ISK \& GDV, Koln; 1998. German

[4] Bilten o sigurnosti cestovnog prometa 2014. Ministarstvo unutarnjih poslova, Zagreb; 2015. Croatian

[5] Solomon D. Accidents on main rural highways related to speed, driver and vehicle. US Department of Commerce, Bureau of Public Roads, Washington, D.C.; 1964.

[6] Garber NJ, Gadiraju R. Speed variance and its influence on accidents. AAA Foundation for Traffic Safety, Washington, D.C.; 1988.

[7] Farmer CM, Retting RA, Lund AK. Effect of 1996 Speed Limit Changes on Motor Vehicle Occupant Fatalities. Insurance Institute for Highway Safety; 1997.

[8] Scientific research project 7 th frame programme EU commission „Intelligent Cooperative Sensing for Improved Traffic Efficiency“ 2012-2013. EC-FP7-317671.

[9] Heydecker BG, Addison JD. Analysis and modelling of traffic flow under variable speed limits. Transportation Research Part C: Emerging Technologies. 2011;19(2):206-217. doi:10.1016/j.trc.2010.05.008

[10] Thomas J, Srinivasan KK, Arasan VT. Vehicle Class Wise Speed-Volume Models for Heterogeneous Traffic. Transport. 2012;27(2):206-217. doi: 10.3846/16484142.2012.697442

[11] Bekhor S, Lotan T, Gitelman V, Morik S. Free-Flow Travel Speed Analysis and Monitoring at the National Level Using Global Positioning System Measurements. Journal of Transportation Engineering. 2013;139(12):12351243. doi: 10.1061/(ASCE)TE.1943-5436.0000607

[12] Jalooli A, Shaghaghi E, Jabbarpour MR, Noor RM, Yeo $\mathrm{H}$, Jung JJ. Intelligent advisory speed limit dedication in highway using VANET. The Scientific World Journal; 2014. doi:10.1155/2014/629412

[13] Yang-Won C. The Activation Plan of Variable Speed Control of Considering Urban Freeway Continuos TrafficCharacteristics (In Busan Metropolitan City). Journal of the Korean Society of Civil Engineers. 2014;34(2): 627-635. doi: 10.12652/Ksce.2014.34.2.0627

[14] Moon JD, Ko YH. Vehicle Speed Measurement using SAD Algorithm. The Journal of The Institute of 
Internet, Broadcasting and Communication. 2014;14(5): 73-79. doi: 10.7236/JIIBC.2014.14.5.73

[15] Mehar A, Chandra S, Velmurugan S. Highway capacity through vissim calibrated for mixed traffic conditions. Journal of Civil Engineering. 2014;18(2):639-645. doi: 10.1007/s12205-014-0440-3

[16] Park J, Murphey YL, McGee R, Kristinsson JG, Kuang ML, Phillips AM. Intelligent Trip Modeling for the Prediction of an Origin-Destination Traveling Speed Profile. IEEE Transactions on Intelligent Transportation Systems. 2014;15(3):1039-1053. doi: 10.1109/ TITS.2013.2294934

[17] Hooper E, Chapman L, Quinn A. The impact of precipitation on speed-flow relationships along a UK motorway corridor. Theoretical and Applied Climatology. 2014;117(1-2):303-316. doi: 10.1007/s00704-0130999-5

[18] Wang TH, John L, Jeremy K. Changmo Impact of Pavement Roughness on Vehicle Free-Flow Speed. Journal of Transportation Engineering. 2014;140(9). doi: 10.1061/(ASCE)TE.1943-5436.0000689

[19] Theofilatos A, Yannis G. A review of the effect of traffic and weather characteristics on road safety. Accident Analysis and Prevention. 2014;72:244-256. doi: 10.1016/j.aap.2014.06.017

[20] Mendes GA, Axhausen KW, Andrade JS Jr, Herrmann HJ. A scenario planning approach for disasters on Swiss road network. International Journal of Modern Physics C. 2014;25(11). 11 p. doi: 10.1142/ S0129183114500673

[21] Chen DA, Ahn S. Variable speed limit control for severe non-recurrent freeway bottlenecks. Transportation
Research Part C-Emerging Technologies. 2015; 51:210-230. doi: 10.1016/j.trc.2014.10.015

[22] Grumert EM, Tapani AX. Analysis of a cooperative variable speed limit system using microscopic traffic simulation. Transportation Research Part C: Emerging Technologies. 2015;52:173-186. doi: 10.1016/ j.trc.2014.11.004

[23] Seo T, Kusakabe T, Asakura Y. Estimation of flow and density using probe vehicles with spacing measurement equipment. Transportation Research Part C: Emerging Technologies. 2015;53:134-150. doi: 10.1016/j.trc.2015.01.033

[24] Chang MF, Chen CH, Lin YB, Chia C-Y. The frequency of CFVD speed report for highway traffic. Wireless Communications \& Mobile Computing. 2015;15(5): 879-888. doi: 10.1002/wcm.2384

[25] Montella A, Punzo V, Chiaradonna S, Mauriello F, Montanino M. Point-to-point speed enforcement systems: Speed limits design criteria and analysis of drivers' compliance. Transportation Research Part C: Emerging Technologies. 2015;53:1-18. doi: 10.1016/j. trc.2015.01.025

[26] Jamshidnejad A, De Schutter B. Estimation of the generalised average traffic speed based on microscopic measurements. Transportmetrica A-Transport Science. 2015;11(6):525-546. doi: 10.1080/23249935.2015.1026957

[27] Horvat R, Kos G, Ševrović M. Traffic Flow Modelling on the Road Network in the Cities. Technical Gazette. 2015;22(2):475-486. doi: 10.17559/ TV-20150127093334 